\title{
Distribution, Phenology, and Ecology of Hopea Genus (Family: Dipterocarpaceae) in India - A Review
}

\author{
B. Madhusudhana Reddy ${ }^{1 *}$, G. S. Uma ${ }^{3}$, Lokinder Sharma ${ }^{2}$ and T. N. Manohara ${ }^{1}$ \\ ${ }^{1}$ Silviculture and Forest Management Division, Institute of Wood Science \\ and Technology, Bengaluru- 560003, Karnataka, India \\ ${ }^{2}$ Forest Research Institute Deemed to be University, Dehradun, India \\ ${ }^{3}$ Indian Agricultural Research Institute, New Delhi, India \\ *Corresponding author
}

\section{A B S T R A C T}

\section{Keywords}

Hopea, Endemic,

Western Ghats,

Dipterocarps,

Phenology,

Ecology,

Distribution,

Effective

conservation.

\section{Article Info}

Accepted:

07 September 2020

Available Online:

10 October 2020
Hopea genus is represented by timber yielding large trees, present in the evergreen and semi-evergreen forest. This genus comprises 104 species distributed globally among them 11 species are present in India of which eight are endemic to the Western Ghats. It was found that fragmentation of habitat; land cover change and overexploitation are the major driving factors responsible for the severe decline in their natural population. Most of the Dipterocarps, viz., H. erosa, H. Jacobi, and H. racophloea are only known from limited localities and their high degree of habitat specificity makes them rare. To device strategies for effective conservation of Hopea, information on its distribution, phenology, and ecology is very much essential.

\section{Introduction}

India is one of the world's 'mega diversity' countries, out of the 18 global biodiversity hotspots India has 4 of them namely the Eastern Himalaya and The Western Ghats, Indo-Burma Region, and Sundaland. Because of higher plant species richness, with ten distinct biogeographic zones, India possesses ninth position in the world. According to
India State of Forest Report (ISFR) - 2019, India with $24.56 \%$ of land area under forest and tree cover, even though it accounts for 2.4 $\%$ of the world's surface area and sustains the needs of $17 \%$ of the total human population along with $18 \%$ of the total livestock. The Western Ghats covers a territory around $1,60,000 \mathrm{~km}^{2}$ and stretches for 1,600 km from Tamil Nadu in the south to Gujarat in the north, separated only by the $30 \mathrm{~km}$ Palakkad 
Gap. Precipitation pattern and geographical variation results into a large variety of vegetation types such as scrub forests present in the low-lying rain shadow areas, rainforests present the plains, deciduous and tropical present at medium elevation, and a unique mosaic of montane forests, rolling grasslands present at a higher elevation. The Western Ghats have very nearly 5,000 vascular plant species belonging to 2,200 genera. Among them about are 1,700 (34\%) endemic species, where 58 are monotypic endemic plant genera. Some significant genera and families are consisting of huge numbers of endemic species, for example, Impatiens with 76 of 86 species endemic, Dipterocarpus with 12 of 13 species endemic. Among the 490 tree species recorded from forests of low and midelevation, 308 are endemic species, 130 are endemic out of 267 orchids (BSIENVIS, 2016). The fossil evidence Dipterocarps from Burma, Bangladesh, Eastern India, and Southern India speaks that they were the significant component of the ancient flora. RAPA Monograph, 1985 reported that Dipterocarps pollen has been collected from Kutch they are presentative of Eocene. The Hopea genus belongs to the Dipterocarpaceae family and shown the pan-India presence. Hopea parviflora, along with their timber value, the bark is a good candidate for tanning material, mainly for heavy leather. The bark possesses $70 \%$ tannin and $22.6 \%$ non- tannin, used as an astringent (Kamarudeen, 2003) and stilbenoids have effective biological properties produced by Dipterocarpaceous plants (Rose, 2013). The methanolic extract of $H$. ponga leaf possess important biological activities such as antioxidant and antibacterial (against bacteria Proteus vulgaris), and also used for treating Proteus infections. H. ponga leaf contains a higher amount of phenolic and flavonoid content compared to another member of the family Dipterocarpaceae and other species in the Hopea genus have various uses. The Western Ghats forests are selectively logged and highly fragmented, in some area converted to agricultural land for monoculture plantations of coffee, tea, rubber, teak, Eucalyptus, oil palm, and wattle, and are also cleared for building, roads, reservoirs, and railways. Encroachment inside the protected areas lead to reducing the extent of the forest, cattle, and goats grazing within and near protected areas caused drastic forest slopes erosion. Tree communities altered in forests of the tropical region due to habit loss and fragmentation of the population (Laurance et al. 2006). The United Nations Educational, Scientific, and Cultural Organization (UNESCO) has recognized the Western Ghats as one of the Natural World Heritage sites based on its remarkable natural habitats. In this context, present authors felt the necessity to understand the Indian distribution, phenology, and ecological aspects of the Hopea genus.

\section{Distribution of different species of Hopea genus in India}

Dipterocarpaceae is an important dicot plant family having almost 580-680 species. They are present throughout the tropical region, for example Northern South America to Africa, Seychelles, Philippines, India, Sri Lanka, China, Indonesia, Thailand, and Malaysia. This family is divided into 3 subfamilies: (i) Monotoideae having 30 species and 3 genera and present across Madagascar, Africa, and South America (ii) Pakaraimoideae having single species for example Pakaraima earoraimae present in the Guaianan highlands of South America, and (iii) Dipterocarpoideae nearly 470 species of 13 genera, present mostly in South Asian countries to be specific India, Phillippines, Sri Lanka, Indonesia, New Guinea, Thailand, China, and Malaysia except for Vateriopsis seychellarum an endemic to Seychelles. Dipterocarpaceae and Shoreae belong to the sub-family Dipterocarpoideae (Brandis, 1895). The genera belong to the 
Shoreae tribe are Hopea, Dryobalanops, Parashorea, Neobalanocarpus, and Shorea having imbricate sepals in fruits, grouped vessels, resin canals in tangential bands, and basic chromosome number $\mathrm{n}=7$ (Gamage,

2006). The species of the family are found in both lowland rainforests (evergreen in nature) and also in seasonal upland or more xerophytic forests (Irudhyaraj, 2016).

(c)

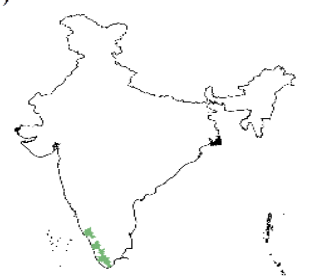

(e)
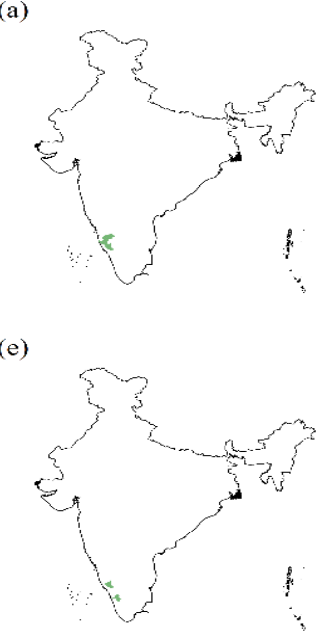

(i)

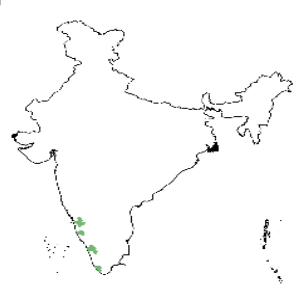

(f)

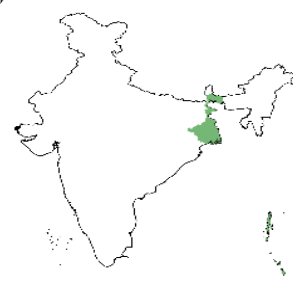

(i)

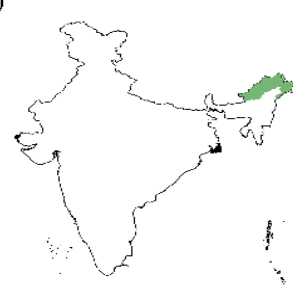

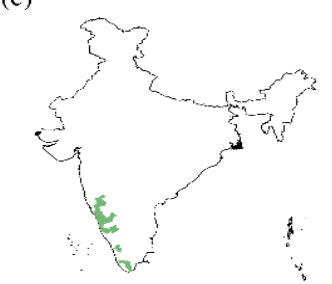

(g)

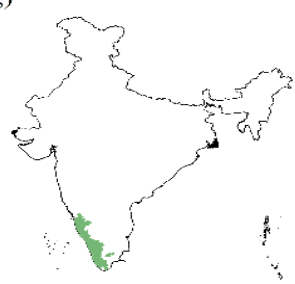

(k)

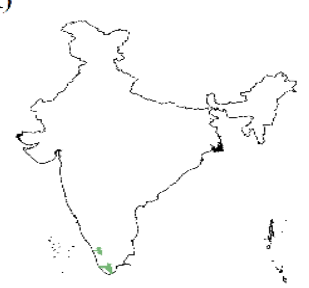

(d)

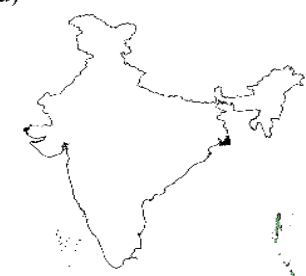

(h)

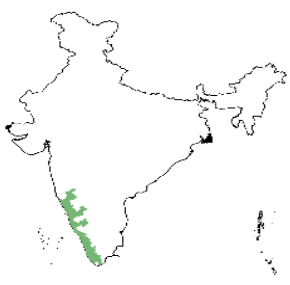

Plate 1. Showing distribution of Hopea genus in India. (a) Hopeacanarensis. (b) H. erosa (c) H. glabra (d) H. helferi (e) H. jacobi (f) H. odorata (g) H. parviflora (h) H. ponga (i) H. racophloea(j) H. shingkeng (k) H. utilis

Approximately 31 Dipterocarps species have been reported and restricted to northern India whereas the Western Ghats possess 17 species belonging to 5 genera viz. Hopea, Dipterocarpus, Shorea, Vateria, and Vatica. Member of Hopea, a potent timber yielding genus is represented by larger trees present in the evergreen and semi-evergreen forest. This genus has 104 species present worldwide and 11 species present in India (Irudhyaraj, 2016). Generally, Indian species of Hopea were endemic, out of the 11 species 8 species are recorded as endemic to the Western Ghats mainly to the states of Kerala, Karnataka, and Tamil Nadu. Most of the Indian species of the genus reported under severe threat and were included in the IUCN red list. Two species viz., Hopea erosa (Bedd.) Slooten (IUCN, 1998) and Hopea jacobi C.E.C. Fisch (IUCN, 1998) were included under critically endangered, six species Hopea glabra Wight \& Arn(IUCN, 1998), Hopea canarensis Hole (IUCN, 2017), Hopea helferi Dyer Brandis (IUCN, 2017), Hopea ponga 
(Dennst.) Mabb(IUCN, 1998), Hopea ra cophloea D yer (IUCN, 1998), and Hopea utilis Bedd. Bole (IUCN, 1998) included under endangered, Hopea odorata Roxb (IUCN, 2017) was included in vulnerable, Hopea parviflora Bedd (IUCN, 2018) included under the least concern category and Hopea shingkeng (Dunn) Boris (IUCN, 1998) was an endemic species of North India that was extinct in the last decades. H. jacobi was collected from the evergreen forest's region of Coorg, but in the recent past has not been collected from its type locality or any other places. Hence, the species is believed to be extinct (Shetty et al., 2002) then some researchers conducted a detailed floristic survey of $H$. Jacobi to know the exact status and the reasons for the absence or extinction from its type locality (Irudhyaraj, 2016). $H$. erosa has become rare in evergreen forests with mid-elevation, recorded from Anamalai and Agastyamalai hill range, a small population also exists in the Kodagu district of Karnataka (Rao et al., 2019). H canarensis is found in its type locality i.e Andar Reserve Forest and in a few patches of the Kudremukh region, while $H$ ponga, enjoys a very wide distribution spreading into new areas similarly, $H$ parviflora was found in almost all forests.

\section{Phenology of Hopea genus}

The phenological studies revealed the period of various growth activities of the species. Because of the overexploitation, the population of Dipterocarps is being reduced. The recalcitrant nature of the seeds of Dipterocarps limits viability with reduced dormancy. The phenological data i.e. the period of seed maturation and dispersal period helps in seeds collection of species belongs to the Dipterocarps genera specially Dipterocarpus indicus, an endangered species, Vatica chinensis, and H. canarensis were exhibited a narrow distribution (Raj,
2006). The striking feature of many Dipterocarp forest is the phenomenon of mass flowering followed by mass fruiting. Flowers are small and abundant in Hopea. Fruiting is erratic and seed germination is epigeal in Hopea. Inefficient and poor seed dispersal mechanisms are responsible for gregarious formations of Dipterocarps. An in-depth study into the vegetative, as well as reproductive phenology of these species, would shed more light on these abnormalities. Recent climatological changes also influence the regeneration status of the species. Good seed fall and adequate rainfall are necessary for better regeneration because the seeds lose their viability rapidly. Under natural conditions, seeds of $H$. parviflora shed with relatively high-water content (fresh weight basis). These seeds are highly desiccation sensitive and an in-depth study is needed for more information about the recalcitrant nature of the species. Prolific seeding occurs in $H$. parviflora once in 4 -6 years and such years are invariably followed by one or two years of comparative sterility and the same number of moderate seed years (Kamarudeen, 2003). The fruits are poorly protected and often eaten by wild pigs, enormously parasitized by weevils as a result managing Dipterocarps seed production is tiring. The trees of Dipterocarps also take $20-30$ years for its first flowering and the seeds are recalcitrant and unable to store for a long period. Many species of Hopea produced generally short-lived seeds that are not able to combat desiccation. The critical moisture contents of $H$. parviflora and $H$. ponga were about $26 \%$ and $27 \%$ respectively below which they fail to germinate. Hopea is dry capsular as a result moisture content is reduced suddenly after detachment (Irudhyaraj, 2016).

The leaf shedding in $H$. ponga occurs partially during the dry season but the tree appears with photosynthetic leaves throughout the year. The leaf flushing of $H$. 
ponga was observed during June once after the dry season along with the onset of monsoon season in the study area. The studies on the phenology of tropical moist forest in Uttara Kannada of Karnataka by Bhat (1992) showed, the leaf flushing recorded as higher in the pre-monsoon dry period when the rainfall was minimum. Further, $H$. ponga was found to be a lowland tree that produced their young leaves in the rainy season. Shorearhoxburgii a member of the family Dipterocarpaceae showed leaf flushing beyond the complete fruit dispersal (Raju et al., 2011). A similar kind of result was observed on $H$. ponga. The flowering was followed by fruiting in $H$. ponga. The fruit development occurred in the dry season and fruit set and dispersal occurred before the monsoon. The timing of fruiting may also be under some selective pressure to disperse the seeds at the start of the rainy season to facilitate germination. The fruits dispersal of $H$. ponga started during June at which the study sites receive rainfall. The phenological investigation on different phenophase events of $H$. ponga showed annual leaf flushing, flowering, and fruiting. However, it was a mass flowering species that has slight oscillation in the flowering, and few individuals observed to develop flowers once in two years. The floral biology of $H$. ponga showed that the species produced hermaphrodite flowers in axillary racemes. $H$. ponga produced $79.56 \pm 18.3$ number of flowers per inflorescence. The enormous flower production makes $H$. ponga as mass flowering species and this phenomenon was a typical flowering pattern of all Dipterocarpaceae members. This mass flowering behavior of the species may helpful for the attraction of more pollinators. Usually, the members of the genus Hopea have 15 - 18 anthers per flower (Janardhanan, 1993). The seed biological studies showed that the seeds of $H$. ponga were recalcitrant. The studies on the seed moisture content showed that the seeds of $H$. ponga recorded a maximum moisture content of $73.2 \%$ and get reduced to below $1 \%$ after 45 days. Similarly, the viability studies showed that in the case of $H$. ponga, the viability of the seed was $93.5 \%$ at the detached stage and completely lost after one month of storage. These results were confirmed that the seed was recalcitrant that lost its viability within a short period of storage. Further, the germination studies showed that in the case of $H$. ponga, the seed germination starts immediately after the detachment and showed $84 \%$ of germination. This germination percentage was reduced drastically in the subsequent days and lost after the storage of one month. The results on the seed biology of $H$. ponga were not similar to the findings of Sukesh and Chandrashekar (2011) in which, the germination percentage was slightly lower than their observation. It has been previously reported that the germination of $H$. ponga fails when the critical moisture content has reduced below 27\% (Dayal and Kaveriappa, 2000) which also coincided with our result. Further, Sukesh and Chandrashekar (2011) reported that the seeds of $H$. ponga stored in open condition lost their viability completely within 11 days. The seeds of many species of Dipterocarpaceae are generally short-lived and cannot withstand desiccation and hence, the failure of monsoon has a specific role in the drastic reduction of the seed germination of $H$. ponga.

In $H$. parviflora, yellowish-green foliage appeared from October onwards, imparting a very impressive appearance, and peak flushing was observed during November. The newly developed leaves appeared along with mature leaves and the colour changed to light green and then to dark green on maturity. The flower initiation starts during the light green stage of leaves. Observations revealed that the majority of flowers appeared at the tip region of the branches. The flowering and fruiting of 
H. parviflora study reveal that flowering was sporadic, with gregarious flowering occurring once in 2-5 years followed by infrequent, irregular flowering activities. The disparity in the timing (period) of flower initiation was also noted in the species. The flower initiation started from December onwards. Premature abscission and Insect attack of flower buds were observed. Flowers are bisexual, creamy white, and fragrant. Leaf flushing occurred every year, but flowering was noted only at 25 years interval. Seed with good vigour often occurs after a gap of 3-5 years. Certain plants located in isolated habitats showed some unusual flowering behavior during the offseason. The development of flower buds to full bloom required 30-40 days. Anthesis was noted between $2-5 \mathrm{pm}$. In $H$. parviflora the pollination is mainly through the wind (anemophily). In general, during the flowering process in $H$. parviflora, heavy shedding of abortive immature fruits occurred during the first two weeks following anthesis, and about 4 months are required for fruit maturity and they ripened during May-July. Throughout their development, premature abscissions of fruits were noted. Around 2 - 4 lakhs flowers were present in a plus tree during a peak flowering season. But the number of fruit set compared to flowering is very less about $1.5 \%$. The Natural germination of seeds exclusively depends upon climatological conditions i.e. if conditions are not favourable during shedding, the percentage of regeneration was very poor and also the seeds lose their viability within 7 days due to recalcitrant nature. Mature fruits are with brownish fruit wall and persistent calyx. The seeds shed with high moisture content. The fruit has a compact cotyledon with a large embryonal axis and the endosperm is observed like a thin dried film during maturity (Kamarudeen, 2003) (Table 1).

\section{Table.1 Phenological calendar of Hopea genus in India}

\begin{tabular}{|c|c|c|c|c|c|c|c|}
\hline \multirow{2}{*}{$\begin{array}{l}\text { Sl. } \\
\text { No. }\end{array}$} & \multirow[t]{2}{*}{ Scientific name } & \multicolumn{6}{|c|}{ Phenology } \\
\hline & & Flushing & Flowering & $\begin{array}{l}\text { Fruit } \\
\text { formation }\end{array}$ & $\begin{array}{l}\text { Fruit } \\
\text { maturation }\end{array}$ & $\begin{array}{l}\text { Fruit } \\
\text { dispersal }\end{array}$ & $\begin{array}{l}\text { Seed } \\
\text { germination and } \\
\text { seedling } \\
\text { establishment }\end{array}$ \\
\hline 1. & $\begin{array}{l}\text { Hopea } \\
\text { canarensis }\end{array}$ & $\begin{array}{l}\text { December- } \\
\text { January } \\
\text { (Raj, 2006) }\end{array}$ & $\begin{array}{l}\text { January-May } \\
\text { (Apnl-May) } \\
\text { (Raj, 2006) }\end{array}$ & $\begin{array}{l}\text { May-August } \\
\text { (Raj, 2006) }\end{array}$ & $\begin{array}{l}\text { August- } \\
\text { September } \\
\text { (Raj, 2006) }\end{array}$ & $\begin{array}{l}\text { September } \\
\text { (Raj, 2006) }\end{array}$ & $\begin{array}{l}\text { September- } \\
\text { October (Raj, } \\
\text { 2006) }\end{array}$ \\
\hline 2. & H. erosa & $\begin{array}{l}\text { Information } \\
\text { not } \\
\text { available }\end{array}$ & $\begin{array}{l}\text { October (Rao } \\
\text { et al., 2019) }\end{array}$ & $\begin{array}{l}\text { January (Rao } \\
\text { et al., 2019) }\end{array}$ & $\begin{array}{l}\text { Information } \\
\text { not } \\
\text { available }\end{array}$ & $\begin{array}{l}\text { Information } \\
\text { not } \\
\text { available }\end{array}$ & $\begin{array}{l}\text { Information not } \\
\text { available }\end{array}$ \\
\hline 3. & H. glabra & $\begin{array}{l}\text { Information } \\
\text { not } \\
\text { available }\end{array}$ & $\begin{array}{l}\text { January (Rao } \\
\text { et al., 2019) }\end{array}$ & $\begin{array}{l}\text { July (Rao et } \\
\text { al., 2019) }\end{array}$ & $\begin{array}{l}\text { Information } \\
\text { not } \\
\text { available }\end{array}$ & $\begin{array}{l}\text { Information } \\
\text { not } \\
\text { available }\end{array}$ & $\begin{array}{l}\text { Information not } \\
\text { available }\end{array}$ \\
\hline 4. & H. helferi & $\begin{array}{l}\text { Information } \\
\text { not } \\
\text { available }\end{array}$ & $\begin{array}{l}\text { January- } \\
\text { February } \\
\text { (IUCN, 2017) }\end{array}$ & $\begin{array}{l}\text { March - } \\
\text { April (IUCN, } \\
\text { 2017) }\end{array}$ & $\begin{array}{l}\text { Information } \\
\text { not } \\
\text { available }\end{array}$ & $\begin{array}{l}\text { Information } \\
\text { not } \\
\text { available }\end{array}$ & $\begin{array}{l}\text { Information not } \\
\text { available }\end{array}$ \\
\hline 5. & H. jacobi & $\begin{array}{l}\text { Information } \\
\text { not } \\
\text { available }\end{array}$ & $\begin{array}{l}\text { Information } \\
\text { not available }\end{array}$ & $\begin{array}{l}\text { Information } \\
\text { not available }\end{array}$ & $\begin{array}{l}\text { Information } \\
\text { not } \\
\text { available }\end{array}$ & $\begin{array}{l}\text { Information } \\
\text { not } \\
\text { available }\end{array}$ & $\begin{array}{l}\text { Information not } \\
\text { available }\end{array}$ \\
\hline 6. & H. odorata & $\begin{array}{l}\text { Information } \\
\text { not } \\
\text { available }\end{array}$ & $\begin{array}{l}\text { February- } \\
\text { March (IUCN, } \\
\text { 2017) }\end{array}$ & $\begin{array}{l}\text { April - May } \\
\text { (IUCN, } \\
\text { 2017) }\end{array}$ & $\begin{array}{l}\text { Information } \\
\text { not } \\
\text { available }\end{array}$ & $\begin{array}{l}\text { Information } \\
\text { not } \\
\text { available }\end{array}$ & $\begin{array}{l}\text { Information not } \\
\text { available }\end{array}$ \\
\hline 7. & H. parviflora & All the & December- & February & May-July & May-July & June-August (Raj, \\
\hline
\end{tabular}




\begin{tabular}{|c|c|c|c|c|c|c|c|}
\hline & & $\begin{array}{l}\text { months } \\
\text { (September- } \\
\text { December) } \\
\text { (Raj, 2006) }\end{array}$ & $\begin{array}{l}\text { May (January- } \\
\text { March) (Raj, } \\
\text { 2006) } \\
\text { (November } \\
\text { IUCN, 2018) }\end{array}$ & $\begin{array}{l}\text { June (Raj, } \\
\text { 2006). } \\
\text { (May IUCN, } \\
\text { 2018) }\end{array}$ & (Raj, 2006) & (Raj, 2006) & 2006) \\
\hline 8. & H. ponga & $\begin{array}{l}\text { Throughout } \\
\text { the year } \\
\text { (October- } \\
\text { March) } \\
\text { (Raj, 2006) }\end{array}$ & $\begin{array}{l}\text { Throughout } \\
\text { the year } \\
\text { including } \\
\text { aseasonal } \\
\text { flowering } \\
\text { (January- } \\
\text { February) } \\
\text { (Raj, 2006) }\end{array}$ & $\begin{array}{l}\text { December - } \\
\text { May (April- } \\
\text { May) (Raj, } \\
\text { 2006) }\end{array}$ & $\begin{array}{l}\text { January- } \\
\text { June (Raj, } \\
\text { 2006) }\end{array}$ & $\begin{array}{l}\text { January- } \\
\text { June (Raj, } \\
\text { 2006) }\end{array}$ & $\begin{array}{l}\text { January-July } \\
\text { (Raj, 2006) }\end{array}$ \\
\hline 9. & H. racophloea & $\begin{array}{l}\text { Information } \\
\text { not } \\
\text { available }\end{array}$ & $\begin{array}{l}\text { February (Rao } \\
\text { et al., 2019) }\end{array}$ & $\begin{array}{l}\text { May (Rao et } \\
\text { al., 2019) }\end{array}$ & $\begin{array}{l}\text { Information } \\
\text { not } \\
\text { available }\end{array}$ & $\begin{array}{l}\text { Information } \\
\text { not } \\
\text { available }\end{array}$ & $\begin{array}{l}\text { Information not } \\
\text { available }\end{array}$ \\
\hline 10. & H. shingkeng & $\begin{array}{l}\text { Information } \\
\text { not } \\
\text { available }\end{array}$ & $\begin{array}{l}\text { Information } \\
\text { not available }\end{array}$ & $\begin{array}{l}\text { Information } \\
\text { not available }\end{array}$ & $\begin{array}{l}\text { Information } \\
\text { not } \\
\text { available }\end{array}$ & $\begin{array}{l}\text { Information } \\
\text { not } \\
\text { available }\end{array}$ & $\begin{array}{l}\text { Information not } \\
\text { available }\end{array}$ \\
\hline 11. & H. utilis & $\begin{array}{l}\text { Information } \\
\text { not } \\
\text { available }\end{array}$ & $\begin{array}{l}\text { March (Rao et } \\
\text { al., 2019) }\end{array}$ & $\begin{array}{l}\text { November } \\
\text { (Rao et al., } \\
2019)\end{array}$ & $\begin{array}{l}\text { Information } \\
\text { not } \\
\text { available }\end{array}$ & $\begin{array}{l}\text { Information } \\
\text { not } \\
\text { available }\end{array}$ & $\begin{array}{l}\text { Information not } \\
\text { available }\end{array}$ \\
\hline
\end{tabular}

\section{Ecology of Hopea genus}

Dipterocarpaceae is one of the dominant families in the evergreen forests of India and Malaysia. Most of the Dipterocarps are wholly evergreen and the others are near the borderline between evergreen and deciduous, approaching the former state in moist localities and the latter in poor dry situations while certain of these become wholly deciduous in dry regions (Troup, 1921). Pascal (1988) carry out a detailed study on the structure, ecology, floristic composition, and succession of Western Ghats wet evergreen forests of India. Dipterocarps consider as important phytoresources in many of the Indian evergreen as well as south-eastern Asian forests. In many places, these species occur as gregarious formations and therefore become dominant members in evergreen and semi-evergreen forests of the Karnataka and other areas. A large number of forest areas in the Western Ghats are dominated by Dipterocarp species. However, there is very little account of the structural aspects of these forests in literature. The Dipterocarps species are being overexploited by human beings for different purposes. As there is no systematically documented data available on forest structural studies dominated by these species, it is tough to take up any measures for their conservation. These forests subjected to massive disturbances, due to the excessive removal of commercially usable timber and unfavourable climatic conditions and other physical and physiological parameters (factors) such as irregular fruiting cycles (seeds produced only every 2-6 years) hastened their depletion (Kamarudeen, 2003). The members of Dipterocarps like $H$. parviflora, $H$. ponga are distributed continuously throughout the Western Ghats with some semi-gregarious formations. However, the species, $H$. canarensis was found only in the Kudremukh region and is restricted in its distribution. H. jacobi was reported from Karnataka in earlier studies, it was not possible to record the same during the recent study. The population of $H$. ponga was severely fragmented in all the study sites with fewer individuals in the restricted forest areas and the sacred grove. H. ponga a reputed commercial timber yielding species, rapidly logged down in the recent past decades and 
the present status speaks that the population is highly fragmented due to its rapid cut down for the timber purpose without proper management strategies. The recent study reported that the populations of $H$. ponga were found as isolated patches in the evergreen forest and lowland. The studies on the phytosociological vegetation of the Alakyam stream revealed that $H$. ponga was the dominant tree species under severe threat (Irudhyaraj, 2016).

Kadambi (1936) reported that the species abundance diminished rapidly with the fall of the altitudes and the lower altitudes were dominated by the species of Lagerstroemia, Terminalia, and Hopea. The genus Hopea was seen atan altitude of 800 - $1000 \mathrm{ft}$. and in altitudes, $\quad 1000-2500 \mathrm{ft}$ species like Poeciloneuron indicum, Dipterocarpus indicus, Mesua ferrea, $H$. parviflora were associated with Palaquium ellipticum, Aglaia odorotissima, Schleicheratrijuga, Canarium strictum, H. wightiana, etc. (Kadambi, 1941). It was reported that the secondary semievergreen type of forest dominated with $H$. parviflorain Karnataka (Bhat, 1993). Ravikumar and Goraya (1999) studied the floristic of the forests of the Kudremukh region of the Western Ghats. The top storey of this forest reaching a height of 35 meters contains species $H$. ponga.

Shetty et al. (2002) while studying observed that 528 taxa of indigenous and exotic plants have become naturalized in Western Ghats and lowlands of Dakshina Kannada and Udupi districts. 176 taxa of trees Dipterocarps like Dipterocarpus indicus, H.parviflora, $H$. ponga, and Vateria indica are also included. $H$. ponga is growing mainly along the sides of streams in evergreen forests at an altitude of $900 \mathrm{~m}$ and the associated species are mainly Hydnocarpus pentandra (Buch.-Ham.) Oken, Palaquium ellipticum (Dalz.) Baill., Polyalthia coffeoides (Thwaites) Hook.f. \&
Thomson, Ancistrocladus heyneanus Wall. ex Graham, Vateria indica L., etc. Only six mature individuals were reported in the dam site and found as a species of the second layer with a very low natural regeneration rate. The poor survival of seedlings might be the reason for the decline in the growth of this population, which needs further investigation. According to Raj (2006) based on the Importance Value Index (IVI) of individual species, different plant associations were observed. However, in some locations, many species were equally important and thus no such associations could be noticed. In the Pilarkan reserve forest, $H$. parviflora was associated with Diospyros bwcifoha. In Charmady, Vateria indica was associated with $H$. ponga, in the Pattighat reserve forest, the association was found to be Vateria indica and $H$. parviflora. However, in the Naravi reserve forest, Vateria indica was found associated with Humboldtiabrunoms and Dipterocarpus indicus. Similarly, in the Nandikoor forest, the formation of $H$. parviflora was observed. In Jadkal forest and Kodyamale reserve forests, $H$. ponga- $H$. parviflora types of associations were observed. The family Dipterocarpaceae with two to four species was dominant in all the forest locations. The density of all the forest locations was higher which is similar to the earlier reports in the Dipterocarp forests and also in other forests. There are reports where the densities of sacred groves are very high since these areas are protected ones. Pilarkan reserve forest is a sacred grove and is well protected. Even in the Nandikoor forest, a part of it is a preserved sacred grove, the density of which is very high in this area when compared to the other forest locations under study. A good species regeneration was noticed in all the studied forest areas. However, the regeneration degrees of different species vary. The regeneration of the dominant species is low in the Pilarkan reserve forest. In this forest, the dominant 
member, $H$. parviflora had a very low regeneration compared to other evergreen species Diospyros buxifoha which exhibited fairly good regeneration. This indicates a likely change in the composition of the forest in the future. In other forest locations the regeneration of members of Dipterocarps is good and also the establishment of these seedlings is faster.

In all the forests the IVI of Dipterocarp species was highest and thus the Dipterocarps are the important components of the area. The association in the Pilarkan Reserve forest was H. parviflora - Diospyros buxifolta type In Jadkal forest and Kodyamale reserve forests it was $H$. ponga - $H$ parviflora type. In Charmady reserve forest the association was Vateria indica $-H$. ponga - Humboldtia brunoms type. In Naravi reserve forest was Dipterocarpus indicus - Humboldtiabrunoms - Vateria indica type. In the Pattighat reserve forest $H$. parviflora - Vateria indica type of association was seen. In the Nandikoor forest, there was no association of species as it was a disturbed site, but $H$. parviflora and $H$. ponga were dominant. In the present study also, Vateria indica was a dominant species associated with $H$. parviflora in the Pattighat reserve forest of Coorg district. In the Pilarkan reserve forest, $H$. parviflora was one of the dominant members in the Jadkal forest, Kodyamale reserve forest, and Nandikoor forests, $H$. parviflora and $H$. ponga were dominant. In Charmady reserve forest, Vateria indica was dominant along with $H$. ponga Thus, in all the seven forest locations, members of Dipterocarps were dominant compared to other species. The highest basal area in the Naravi reserve forest was attributed to more number of trees with big boles. Excepting the Pilarkan reserve forest, in all other forests, the Dipterocarps show a good regeneration. Dipterocarps seedlings in the Pilarkan reserve forest were represented by only $3 \%$ of the total individuals. In all other forest locations, the seedlings of Dipterocarps were more than $20 \%$. In the case of Nandikoor and Naravi forests, the seedlings of Dipterocarps accounted for up to $40 \%$ and $36 \%$ of the total seedlings respectively. This may be because of the openings created in the canopy due to the selective felling of trees for various purposes.

In both the forests, members of Dipterocarpaceae were dominant. In the Pilarkan reserve forest, the local people collect the litter for various purposes. While collecting the litter they also collect the seeds which, reduces the number of seeds available for germination and establishment. The ground vegetation including the herbaceous species was abundant in all the forest locations during the monsoon season except in the Naravi reserve forest and the Pattighat reserve forest. The evergreen vegetation type of Naravi and Pattighat reserve forest with high soil moisture content helps seedlings germination and establishment throughout the year. In other areas, the herbaceous plants and the seedlings of some tree species get dry during the summer season. However, the seedlings of some of the tree species try to survive even with little moisture content and a few succeed to establish in the subsequent periods. The standing volume of different forests of Karnataka and Kerala varied from $839 \mathrm{~m} 3 / \mathrm{ha}$ in Panamberi to $3086 \mathrm{~m} 3 / \mathrm{ha}$ in New Someshwara forests (Pascal, 1988). In all the seven forests, the Dipterocarps were the dominant members in terms of density, basal area, and biovolume. However, the number of species is restricted to a maximum of four in the individual forest locations similar to other forests of Western Ghats of India as reported by Pascal (1988). 
Plate.2 Showing leaves of Hopea genus

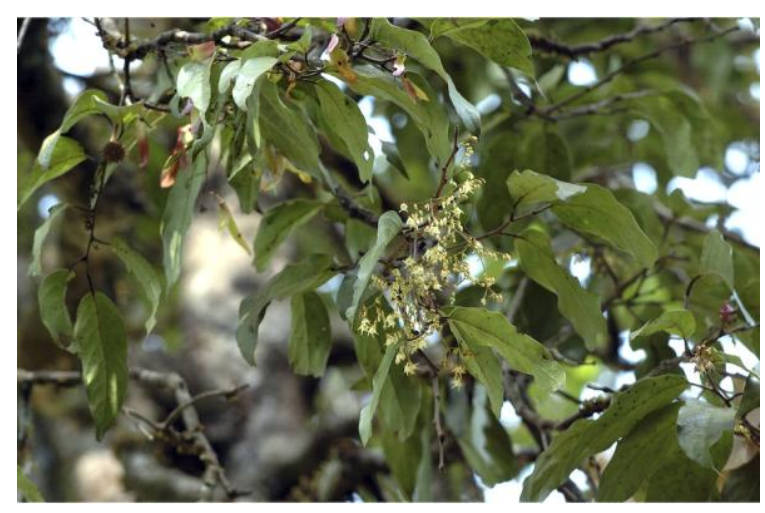

Hopea canarensis

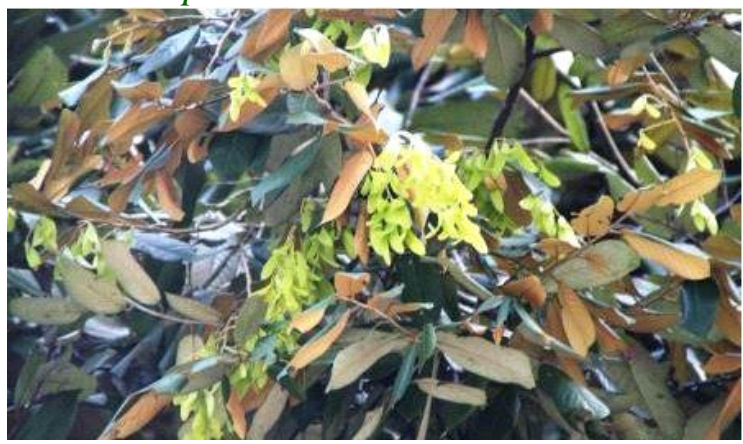

Hopea helferi

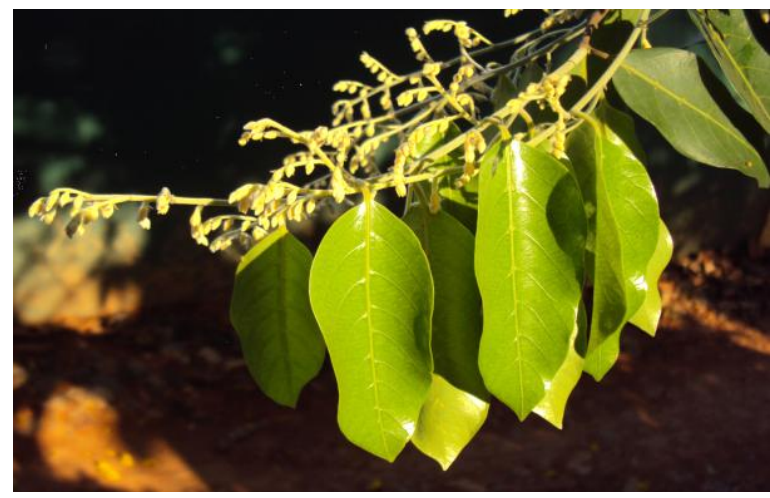

Hopea purviflora

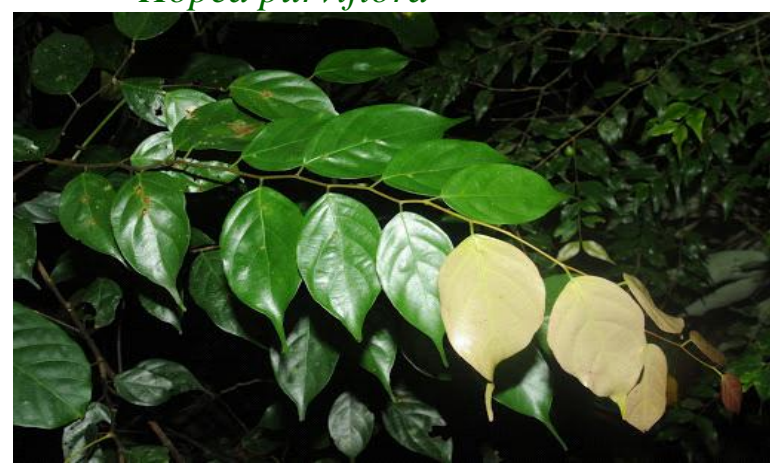

Hopea racophloea

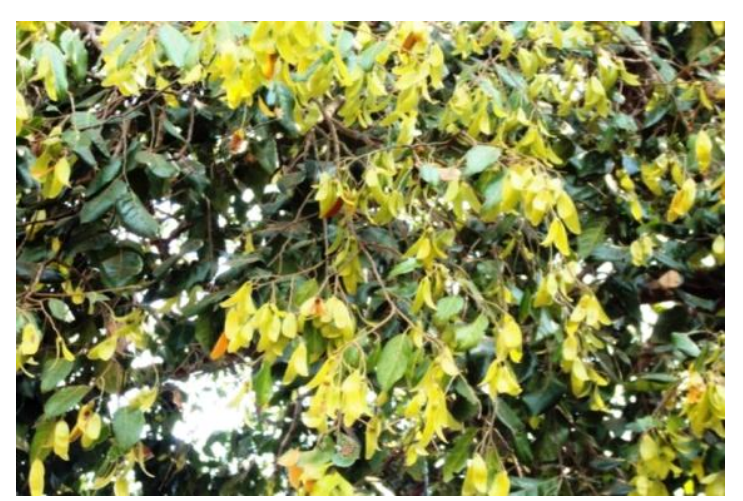

Hopea glabra

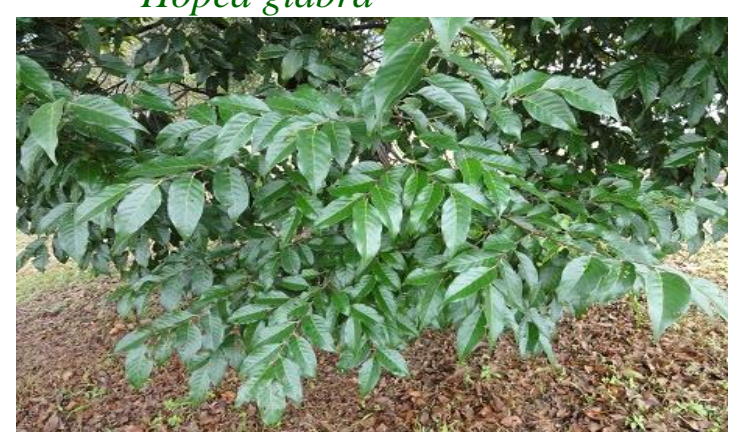

Hopea odorata
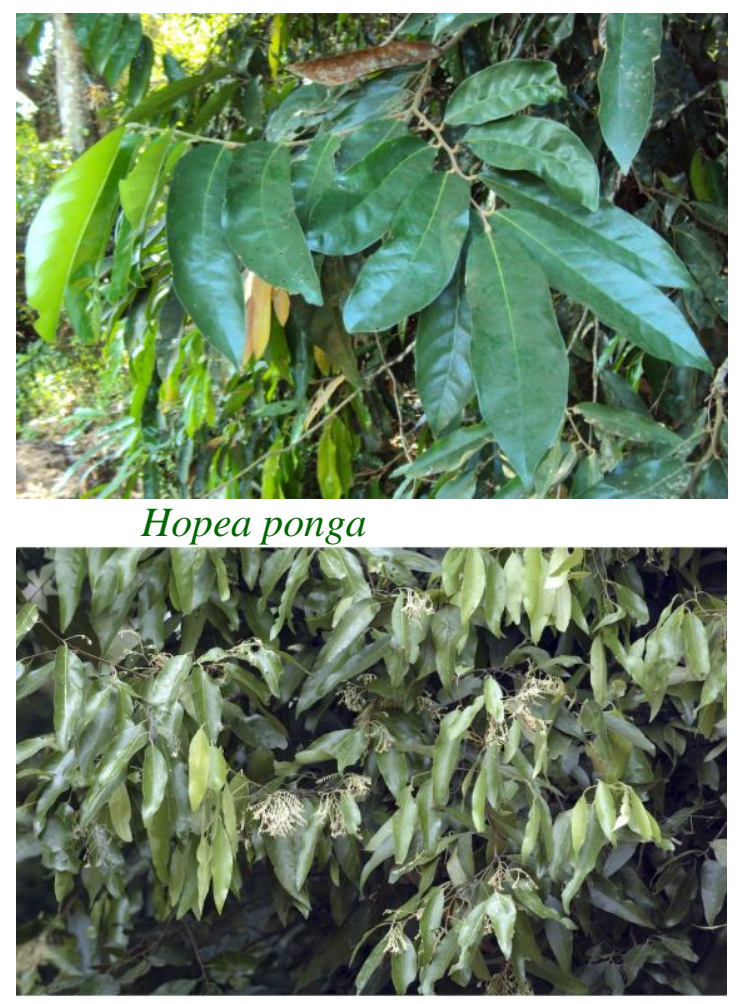

Hopea utilis 
Hopea canarensis Hole. is the shade-loving primary tree species and recorded only in undisturbed forest plots. The species similarity is less than $50 \%$ in the humandominated plots, which implies that anthropogenic pressures had a serious impact on primary forest species, such as Hopea canarensis in the Kudremukh national park. (Nagaraja et al., 2011). Strigulane mathora f. hypothelia grows on leaves of $H$. parviflora Bedd and Strigula orbicularis Fr. shows luxuriant growth on leaves of Hopea canarensis Hole (Subramanya and Krishnamurthy, 2015).

\section{Insects and Pests}

Hopea genus belonging to Dipterocarpaceae is attacked by insects of different orders. The major insect pest of the Hopea genus belongs to coleoptera and hemipteran orders. Beetles and curculionid weevils cause damage by laying eggs on developing floral buds. Beetles also damage anthers and pistils due to intrafloral movement and courtship activities. Beetles are responsible for the maximum percentage of fruit fall (Irudhyaraj, 2016). Mangalorea Hopeae of the Beesoniidae family produces spherical echinate galls on Hopea ponga in leaf axils by modifying vegetative buds. It completely arrests differentiation and development of leaf primordia and develops it into multicellular echinate appendages (Raman and Takagi, 1992).

An ant species Oecophylla smaragdina constructs a nest using leaves and tender twigs thereby affecting the growth of the tree. Trioza Hopea $e$, a psyllid species causes serious damage to Hopea odorata by inducing leaf galls (Burckhardt and $\mathrm{Vu}, 2012$ ). Few butterfly species such as Archopala amantes, Arhopala centaurus, and Triodes minosact as pollinators in the adult stage whereas they act as defoliators in the larval stage (Sukesh,
2014). The rock bee, Apisdorsata also acts as a pollinator. Odontotermeshorni attacks wood of fallen logs of Hopea odorata. In H.ponga severe infestation was observed on fallen fruits by soil-borne weevils which considerably reduced the soil seed bank and subsequent germination (Kamarudeen, 2017). Collected and stored seeds of Hopea canarensis were preyed upon by insects (Viswanathan,2018). The studies related to insect pests of trees belonging to the Hopea genus are limited in numbers and even among those limited studies only a few researchers attempted to identify the insect taxonomically, hence there is a lot of scope for further research on this topic.

Hopea possesses pantropical distribution (Northern South America to Africa, Seychelles, Philippines, India, Sri Lanka, China, Indonesia, Thailand, and Malaysia). This genushas reported with 104 species throughout the world and in India, it is represented by 11 species of which eight are endemic to the Western Ghats. It was found that fragmentation of habitat; land cover change and overexploitation are the major driving factors responsible for the severe decline in their natural population. Hopea shingkeng is extinct and many at the verge of extinction. There is no concerted effort to safeguard the Hopea for posterity. Limited population, fewer numbers of mature individuals, irregularity along with sparse flowering, low fruit setting, heavy immature fruit falls, and recalcitrant nature of seeds, poor regeneration, and survival make it rare. Most of the Dipterocarps, viz., H. erosa, $H$. Jacobi, and $H$. racophloea are only known from limited localities and their high degree of habitat specificity makes them rare. To device strategies for effective conservation of Hopea, information on its distribution, ecology, and phenology is very much essential. 


\section{References}

Ashton, P. 1998. Hopea glabra. The IUCN Red List of Threatened Species 1998: e.T33018A9749319. http://dx.doi.org/10.2305/IUCN.UK.199 8.RLTS.T33018A9749319.en

Ashton, P. 1998. Hopeajacobi. The IUCN Red List of Threatened Species 1998: e.T31169A9610525. http://dx.doi.org/10.2305/IUCN.UK.199 8.RLTS.T31169A9610525.en

Ashton, P. 1998. Hopeaponga. The IUCN Red List of Threatened Species 1998: e.T33470A9786253. http://dx.doi.org/10.2305/IUCN.UK.199 8.RLTS.T33470A9786253.en

Ashton, P. 1998. Hopearacophloea. The IUCN Red List of Threatened Species 1998:

e.T33022A9749968. http://dx.doi.org/10.2305/IUCN.UK.199 8.RLTS.T33022A9749968.en

Ashton, P. 1998. Hopeashingkeng. The IUCN Red List of Threatened Species 1998: e.T33469A9786213.

http://dx.doi.org/10.2305/IUCN.UK.199 8.RLTS.T33469A9786213.en

Ashton, P. 1998. Hopeashingkeng. The IUCN Red List of Threatened Species 1998: e.T33469A9786213.

http://dx.doi.org/10.2305/IUCN.UK.199 8.RLTS.T33469A9786213.en

Ashton, P. 1998. Hopea utilis. The IUCN Red List of Threatened Species 1998: e.T33023A9750096.

http://dx.doi.org/10.2305/IUCN.UK.199 8.RLTS.T33023A9750096.en

Asthon, P.S., (1982) Dipterocarpaceae. Flora Malesiana 9, 237-552.

Barstow, M. 2017. Hopeacanarensis. The IUCN Red List of Threatened Species 2017: e.T33017A118910041. http://dx.doi.org/10.2305/IUCN.UK.201 73.RLTS.T33017A118910041.en

Barstow, M. 2017. Hopea canarensis. The IUCN Red List of Threatened Species
2017:e.T33017A118910041.

http://dx.doi.org/10.2305/IUCN.UK.201 73.RLTS.T33017A118910041.en

Barstow, M. and Deepu, S. 2018. Hopea parviflora. The IUCN Red List of Threatened Species 2018: e.T33021A115932625.http://dx.doi.org/ 10.2305/IUCN.UK.20181.RLTS.T3302 1A115932625.en

Bhat, D. M. 1992. Phenology of tree species of tropical moist forest of Uttara Kannada District, Karnataka, India. J. Biosci.,17( 3): 325 - 352.

Bhat, K.G. 1993. Studies on the vegetation of Pilarkan reserve forest, Dakshina Kannada district Myforest 29: 275-279.

Brandis, D. 1895. An enumeration of the Dipterocarpaceae. J. Linnean Soc. 31, 1148.

BSIENVIS,2016.http://bsienvis.nic.in/files/Bi odiversity\%20Hotspots\%20in\%20India. pdf

Burckhardt,D., and Vu,N. 2012.Triozahopeae sp. nov. (Hemiptera: Triozidae): a pest on Hopea odorata (Malvales: Dipterocarpaceae) in Vietnam. Entomological. 15: 74-80

Conifer Specialist Group. 1998. Hopeaerosa. The IUCN Red List of Threatened Species 1998: e.T31168A9610453. http://dx.doi.org/10.2305/IUCN.UK.199 8.RLTS.T31168A9610453.en

Conservation Outlook rating. 2017. https://www.worldheritageoutlook.iucn. org/explore-sites/wdpaid/555547990

Dayal. B. R. and Kaveriappa, K. M. 2000. Effect of desiccation and temperature on germination and vigour of the seeds of Hopea parviflora Beddome and $H$. ponga (Dennst.) Mabb. Seed sci. Tech., 28(2): 497 - 506.

Gamage, D.T., de Silva, M., Inomat, N.,Yamazaki, T. and Szmidt, A.E., (2006) Comprehensive Molecular 
Phylogeny of the Sub-Family Dipterocarpoideae (Dipterocarpaceae) Based on Chloroplast DNA Sequences. Genes Genet. Syst.81, p.1-12.

Hosagoudar V B and Kamarudeen M. 2002. Asterinalzopeaesp. nov. In: Hosags Studies on Foliicolous Fungi-IV, Zoos' Print Journal, 17(7), 815-816.

Irudhyaraj, D. 2016. Reproductive biology of Elaeocarpus blascoiweibel and Hopeapongadennstmabberley endemic and endangered tree species of Western Ghats. Ph.D Thesis, The Gandhigram Rural Institute, Tamilnadu, India.

ISFR, 2019. Forest Survey of India. https://www.fsi.nic.in/

Janardhanan, K. P. 1993. Dipterocarpaceae. In: Flora of India. Sharma, B. D. and Sanjappa, M. (eds.), Botanical Survey of India, Calcutta.

Kadambi, K. 1936. Observations on the silvicultural characters of Dipterocarpus indicus in the Agumbe forest zone $\mathrm{m}$ Mysore state. Indian Forester 62: 481492.

Kadambi, K. 1941. The evergreen ghat ram forest. Agumbe - Kilandur zone (A study $m$ the tropical ram forest of the Western Ghats of Mysore). Indian Forester 67: 184-203.

Kamarudeen, M. 2003. Physiological and biochemical studies on seeds of Hopea parviflorabedd. and Vateria indicalinn. Two economically important endemic trees of Western Ghats. Ph.D. thesis, University of Kerala, Thiruvananthapuram.

Kamarudeen, M., Jee, G., Babu, K. P.,Anilkumar, C.,Pandurangan, A.G. and Krishnan, P.N. 2017. Phenological and Seed Developmental Studies of Hopea parviflora Bedd.: An Economically Important Endemic Trees of Western Ghats. Journal of Advances in Biological Science Volume 4 (1), 2-6. Laurance, W. F, Nascimento, H. E. M.,
Laurance, S. G., Andrade, A. C. and Fearnside, P. M., 2006. Rain forest fragmentation and the proliferation of successional trees. Ecol., 87(2): 469 482.

Nagaraja, B.C., Raj, M.B., Kavitha, A. and Somashekar, R.K. (2011): Impact of rural community harvesting practices on plant biodiversity in Kudremukh National Park, India, International Journal of Biodiversity Science, Ecosystem Services \& Management, $7: 1,69-74$

Nanthavong, V.K., Pooma, R., Khou, E., Newman, M. and Barstow, M. 2017. Hopeahelferi. The IUCN Red List of Threatened Species 2017: e.T32506A2821025. http://dx.doi.org/10.2305/IUCN.UK.201 7-3.RLTS.T32506A2821025.en

Newman, V.M., Khou, E., Barstow, M., Hoang, V.S., Nanthavong, K. and Pooma, R. 2017. Hopea odorata. The IUCN Red List of Threatened Species 2017:

e.T32305A2813234.http://dx.doi.org/10 .2305/IUCN.UK.20173.RLTS.T32305A 2813234.en

Pascal, J.P. 1988 Wet Evergreen Forests of the Western Ghats of India - Ecology, Structure, Floristic composition and Succession. French Institute, Pondicherry, India, Pp. 345

Primack, R., and Corlett, R. 2005. Tropical Rain Forests: An Ecological and Biogeographical Comparison. Blackwell Pubhlishing, Carnforth.

Raj, B.K.V. 2006. Structural studies of some Dipterocarps forests of the Western Ghats of Karnataka, Ph.D. thesis, Mangalore University, Mangalagangotri.

Raju, A. J. S., Ramana, K. V. and Chandra, P. H. 2011. Reproductive ecology of Shorearox burghii G. Don (Dipterocarpaceae), an endangered 
semievergreen tree species of Peninsular India. J. Threat. Taxa, 3(9): 2061 2070.

Raman, A., and Takagi, S. 1992. Galls induced on Hopeaponga (Dipterocarpaceae) in Southern India and the gall-maker belonging to the Beesoniidae (Homoptera: coccoidea). InsectaMatsumurana. 47: 1-32

Rao, K.S., Raja K Swamy, Deepak Kumar, Arun Singh R. and K. Gopalakrishna Bhat (2019). Flora of Peninsular India. http://peninsula.ces.iisc.ac.in/plants.php ? name $=$ Hopeaerosa. Downloaded on 3 May 2019.

RAPA Monograph, 1985. Dipterocarps of South Asia. Regional Office for Asia and Pacific. 321 pp.

Ravikumar, K. and Goraya, G.S. 1999. Rediscovery of Hopeacanarensis Hole (Dipterocarpaceae) - An endemic and little known species from the Western Ghats of Karnataka, India Indian Journal of Forestry22: 179-182.

Rose, P.M., Saranya, J., Eganathan, P., Jithin, M.M. and Kumar, A.N.P. 2013. In vitro evaluation and comparison of antioxidant and antibacterial activities of leaf extracts of Hopeaponga (Dennst.) Mabberly. Int $\mathrm{J}$ Green Pharm;7:177-81.

Sanil, M.S., Sreekumar V.B., Sreejith K.A. , Robi A.J. and Nirmesh T.K. 2017. Notes on the taxonomy and distribution of two endemic and threatened Dipterocarp trees from the Western Ghats of Kerala, India. Journal of Threatened Taxa. Vol. 9 No. 12
Pp.11033-11039.

Shetty, B.V, Kavenappa, K.M. and Bhat, K.G. 2002. Plant resources of Western Ghats and lowlands of Dakshina Kannada and Udupi Districts. Pilikula Nisarga Dhama Society, Moodushedde, Mangalore. Pp. 264.

Subramanya, S.K. and Krishnamurthy, Y.L. (2015) New distribution records of Strigula (strigulaceae, ascomycota) from the Western Ghats in India. Polish Botanical Journal 60(1): 99-103.

Sukesh and Chandrashekar, K. R. 2011. Biochemical changes during the storage of seeds of Hopeaponga (Dennst.) Mabberly: An endemic species of Western Ghats. Res. J. Seed Sci., 4(2): 106 - 116.

Sukesh, 2014. Mycorrhizal association with some Dipterocarps of Western Ghats and their Molecular Systematics. Ph.D Thesis, Mangalore University, Karnataka, India.

Troup, R. S. 1921. The Silviculture of Indian trees, Clarendon Press, Oxford, UK. vol 1. pp. 1874 - 1939.

Vinayaka, K.S. and Krishnamurthy, Y.L. 2016. Comparative account on Floristic diversity among the two different Tropical Reserved forests of Central Western Ghats, Karnataka, India. Int. Res. J. Biological Sci., 5(5): 26-34.

Viswanathan, A. 2018. The Influence of Fragment Size on Biotic Interactions that structure Plant Communities in the Asian Tropics. Ph.D Thesis submitted to ETH, Zurich.

\section{How to cite this article:}

Madhusudhana Reddy, B., G. S. Uma, Lokinder Sharma and Manohara, T. N. 2020. Distribution, Phenology, and Ecology of Hopea Genus (Family: Dipterocarpaceae) in India - A Review. Int.J.Curr.Microbiol.App.Sci. 9(10): 496-509. doi: https://doi.org/10.20546/ijcmas.2020.910.060 